\title{
MEDIA FRAMING THE RECEPTION OF UNMANNED AERIAL VEHICLES IN THE UNITED STATES OF AMERICA
}

\author{
Patricia K. Freeman ${ }^{a}$, Robert S. Freeland ${ }^{b, *}$ \\ ${ }^{a}$ Department of Political Science, The University of Tennessee, Knoxville, TN, USA \\ ${ }^{\mathrm{b}}$ Department of Biosystems Engineering and Soil Science, The University of Tennessee, 2506 EJ \\ Chapman Dr., Knoxville, TN, 37996-4531 USA, email: rfreelan@utk.edu ph. 865-974-7140
}

Corresponding Author: Robert S. Freeland, email: rfreelan@utk.edu ph. 865-974-7140

\section{ABSTRACT}

9

When the United States Congress mandated implementation of unmanned aerial vehicles (UAVs) into the domestic airspace in 2012, there was substantial opposition to the policy change. Critics expressed fears regarding their threat to privacy and safety, and legislatures considered numerous bills that would significantly limit or even ban domestic unmanned flight. UAV advocates used various methods to counter UAV's negative image.

This study examines media stories regarding UAVs over a four-year period (2011-2014) and demonstrates that despite the backlash against expansion, media frames emphasizing benefit rather than risk dominated in the U.S. media. The economic opportunities presented by UAVs appeared in most media reports and over time reports increased of relatively noncontroversial applications, such as agriculture. Citizen advocacy or frames that emphasized the personal freedom to fly a UAV also increased. Industry and university officials, who usually support expansion, were the most frequent sponsors of media statements. The framing of media reports can influence public debate. Potential risks of a new technology can be amplified or minimized depending on how the media present the issue to the public.

Keywords: Drones, FAA, Media Framing, UAV 
24 Abbreviations. AUVSI-Association for Unmanned Vehicle Systems International, FAA-U.S. Federal Aviation Administration, UAV-Unmanned Aerial Vehicle, UAS-Unmanned Aerial 


\section{INTRODUCTION}

Unmanned aircraft vehicles (UAVs) have until recently been associated with lethal military operations by the United States of America (U.S.). However, there has been growing interest in their domestic applications since the adoption of the Federal Aviation Administration (FAA) Modernization Act of 2012 (PL 112-95), which mandated that the FAA safely integrate commercial UAVs into American airspace by September 2015. Advocates of unmanned aircraft claim that they can make significant contributions in the fields of criminal justice, agriculture, journalism, film production, and search and rescue. However, this emerging technology faced significant roadblocks to acceptance after the Congressional mandate to integrate UAVs into the domestic airspace. The FAA proceeded very slowly to draft regulations to allow commercial flight, citing safety concerns. Further, UAV supporters confronted hostile public opinion and state and federal lawmakers suspicious of the legalization for domestic use.

This analysis examines how the U.S. media over a four-year period (2011-2014) has covered the implementation of UAVs into domestic airspace. Like many emerging technologies, domestic unmanned flight combines risk with a high level of potential benefit. It has also been highly politicized. The paper starts with a description of the political and regulatory environment surrounding domestic unmanned flight after Congress authorized its expansion. It then presents a discussion of media framing and the research questions examined regarding the media and unmanned domestic flight. After reviewing the project's research design and methods, the paper discusses the findings regarding the media's coverage of UAVs. It concludes with suggestions for future research.

\subsection{Contentious EnVIRonMENT FOR DOMESTIC Drone EXPANSION} Domestic UAV uses raised complex issues, privacy, and safety in particular (Bennett, 2012; 
52

unease; a survey reported that $63 \%$ of Americans were opposed to drones flying through most of U.S. airspace (A. Smith, 2014). The intensity of the opposition was apparent in the policy debates. One town passed an ordinance banning all drones (Sullivan, 2013), and at least one other municipality considered issuing licenses to shoot down drones (Steinmetz, 2014). There were impassioned speeches in Congress pointing to the dangers of UAVs (Kaminski, 2013; Villasenor, 2013), but it was the U.S. states where most of the political activity to restrict UAVs has taken place (National Conference of State Legislatures, 2015).

Between 2012 and 2015, almost 500 UAV-related bills have been introduced in the U.S. states, and several states adopted laws restricting UAV use (National Conference of State Legislatures, 2015). UAV supporters had reason to fear that legitimacy would never develop; proposed legislation in some states would prohibit UAV ownership or make it illegal to take aerial photography. Some states would allow aerial photography only if the landowner has given permission (Bohm, 2014; Nanjia, 2014). One bill analysis reported that regulations that prohibit UAV use over private property will significantly limit or even end most commercial and research use of UAVs (Rainwater, 2013).

The opposition cited safety concerns. Military UAVs have high crash numbers (McGarry, 2012), and some have pointed to the danger to winged aircraft from unmanned flights (Whitlock, 2014). Government officials had also raised the possibility that UAVs could be hijacked by disrupting or taking control of the UAV's non-encrypted signals from the Global Positioning System (Brewin, 2013). Several incidents raised concerns regarding the safety and the liability that flyers of recreational and especially commercial UAVs may face. Operators have lost control of UAVs in public areas (Jones, 2014), in one case killing a man (Goodman, 2013). 
UAV advocates worked to counter the negative press reports and prevent the adoption of restrictive legislation. To differentiate domestic UAVs from militarized UAVs, the term "drone"

77 was never to be used by industry (MacGillis, 2013; Morley, 2012). Positive projections

78 regarding drones' impact on economic development were widely disseminated, with the

79 agricultural sector receiving particular attention (Traverse, 2013) (Fig. 1).

80

81

82

83

84

85

86

87

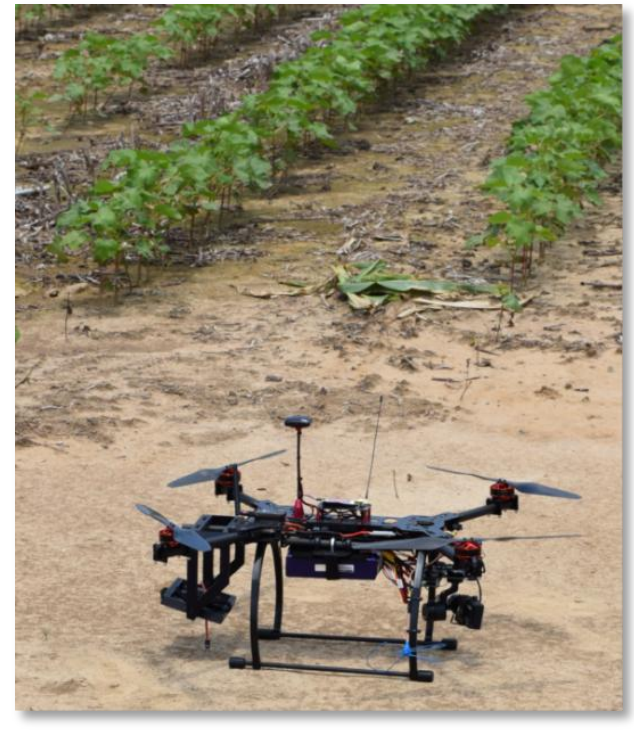

Fig. 1. Agricultural UAV used for commercial crop scouting

In 2012-2013 news of militarized drones (Fig. 2) combined with revelations that the U.S. National Security Agency was collecting information on millions of people produced strong resistance to the Congressional mandate to integrate UAVs into U.S. airspace. Were domestic UAVs useful tools producing tremendous economic benefit or spying robots that could create significant safety hazards? The way in which UAVs were framed in the media would likely play an important role in the development of their legitimacy. 


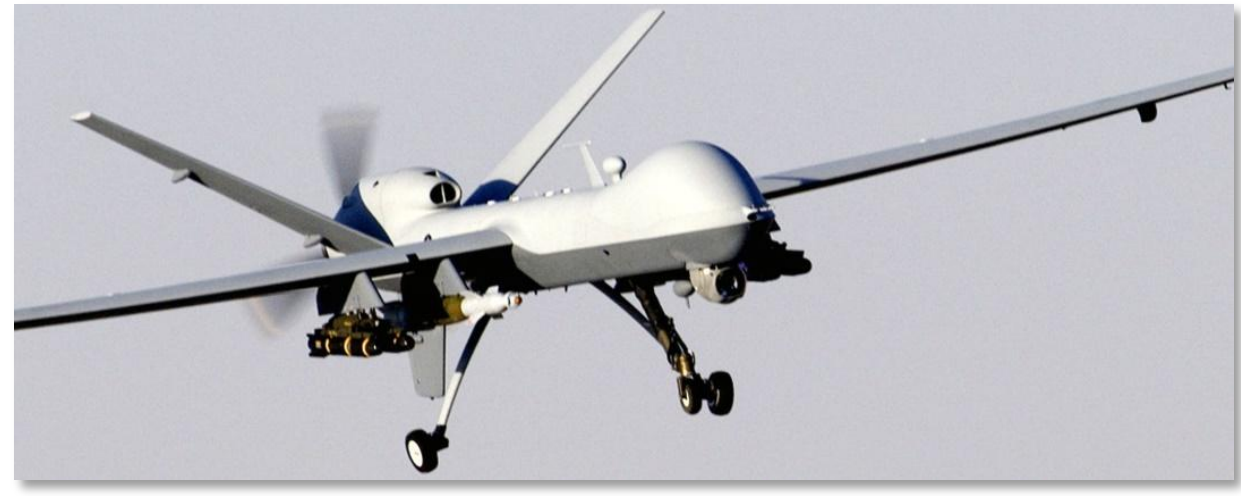

Fig. 2. Weaponized UAV-MQ-9 Reaper in flight (Ferguson, 2007).

\subsection{Framing, The Media, ANd UAVS}

Considerable research shows that media framing can play an important role in views formed around emerging technologies (B. Scheufele, 2006). Media frames refer to the way journalists, groups, policymakers, and others interested in a particular public policy present information. A frame highlights some aspects of reality while concealing facts as it typically makes more salient targeted information or perspectives (de Vreese, 2012; Entman, 1993; Entman, Matthes, \& Pellicano, 2009). Journalists frame stories with the goal of making the complex information interesting and understandable (Gitlin, 1980). Policy actors use media framing to persuade. A frame may suggest the superiority of some types of political action over others (Chong \& Druckman, 2007; Slothuus \& de Vreese, 2010). Effective framing can mobilize supporters for an issue, increase support, and demobilize antagonists (Benford \& Snow, 2000; W. A. Gamson \& Modigliani, 1989; Pan \& Kosicki, 2001; Polletta \& Ho, 2006; Reese, Gandy Jr, \& Grant, 2001). Political actors may strategically provide information to journalists with the with the goal of dominating the frames presented (Entman, 1993; L'Etang \& Merkelsen, 2011; M. A. Smith, 2000).

This study analyzes how the U.S. media has covered the contentious issue of domestic UAV expansion. Unmanned flight differs from other public policies such as nanotechnology or bioengineering. Most Americans have observed or can visualize UAVs. The public's knowledge 
of UAV's potential is likely much higher than with many other technologies, but potential dangers are also better understood. Thus, the pattern of media coverage of UAVs may or may not parallel the media's reporting of other science and technology policies.

The following questions are addressed over the four-year study period:

1. What frames are present in the media coverage of domestic expansion?

2. Has coverage of domestic applications changed through the study period? UAVs have a variety of uses. While some applications, such as agriculture, are relatively noncontroversial, UAV deployment by law enforcement has met with considerable resistance.

3. What types of UAV applications are identified in the articles?

4. Who is the source of the statistics, quotes, or paraphrased statements that appear in the articles about UAVs? Coding is done for each article to ascertain who is providing the information appearing in the media reports. The first three sources in each article are categorized. An analysis of media sources provides context regarding the articles beyond the frame used.

5. Are there a variety of sources for the statistics, quotes and paraphrased statements and are they representative of the pattern often found in reporting on science and technology?

6. When citizens rather than interest groups, government officials, or scientists are the source of media statements, are these statements supportive of UAV expansion or not? The tone of citizen comments regarding domestic expansion were coded to provide insight into the role of the U.S. public in the media coverage. 


\subsection{Sources ANd Methods}

Keyword searches of an online data bank using only U.S. sources supplied the analyzed stories. It contained current and archived content from local (serving a city or region) and national (circulates through the whole country) newspapers, blogs, newswires, journals, broadcast transcripts and videos. This news bank (Access World News: Research Collection, NewsBank Inc., Naples, Fla.) included a total of 6,227 sources and content from all 50 states (Hart, 2014; NewsBank Inc., 2015). Since the U.S. Congress mandated the implementation of UAVs into domestic U.S. airspace in 2012, beginning in 2011 provides information regarding expectations before there were controversial discussions of domestic UAV commercial flights. An inductive approach derived the keywords used in the search of news articles and to construct a classification scheme for the content of UAV new stories (Abrahamson, 1983). After scanning a large number of the news stories, it was determined that two keyword searches would yield the most comprehensive list of media reports that focused on domestic UAVs. One search used the keywords "unmanned aircraft" and the second search used the keywords "unmanned aerial." The commonly used term "drone" was not a keyword because it produced articles that were not related to unmanned flight. Most articles employing the word drone that involved UAVs also contained the terms unmanned aircraft or unmanned aerial. Furthermore, news stories used the terms "unmanned aircraft" or "unmanned aerial" that did not contain the word drone.

The keyword searches scanned only the first or lead paragraph of each story. Since the lead paragraph is the most prominent element in the text (Di Gregorio, Price, Saunders, \& Brockhaus, 2013), this selection method allows us to distinguish the news stories with UAVs as a focus rather than a secondary story line. Of the articles identified, we eliminated any stories that did not deal with the domestic deployment of UAVs. If a story appeared in both searches, 
153 154 155 156 157 158 159 160 161 162 163 164 165 166 167 168 169 170 171 172 173 174 175

only one was considered. The analysis did not consider articles that consisted of only business or stock reports.

The news articles left were presented in chronological order. A skip interval was used to select every other story for analysis. This process yielded the following number of reports per year: 300 for 2011, 416 for 2012, 652 for 2013, and 505 for 2014.

According to Entman (1993), news selection and salience are the theoretical bases for framing. Using Entman's definition of issue framing, frames promote a particular problem definition, suggest causal relationships, and offer a moral evaluation or suggestion solutions to the problem. To develop a set of issue frames that adequately address the news coverage of UAV expansion, we read a large number of press reports to identify the common narratives regarding this technology

In addition to the press articles, we reviewed the material disseminated by industry and a wide range of nonprofit organizations (Boykoff, 2008). Legislative research reports were analyzed along with the information disseminated by the FAA. Using these sources, we identified three types of issue frames that describe virtually all of the stories regarding domestic UAVs in the U.S. These frames also encompass the news frame categories used in other analyses of media framing of science and technology (Anderson, Allan, Petersen, \& Wilkinson, 2005; Lively, Conroy, Weaver, \& Bimber, 2012; Nisbet \& Huge, 2006). Four frames involve benefits from UAV expansion while two frames encompass the risks that accompany expansion. Regulation constitutes the third frame. There are four types of Benefit Frames. One describes the economic development that the domestic UAV will provide, which included references to job growth and improved increased revenue for the U.S. jurisdiction that allows expansion. A second frame discusses the advocacy of citizens who want 
expansion because they perceive recreational or commercial benefits. A third Benefit Frame contains descriptions of how domestic UAV applications can make work easier and safer (e.g., agriculture, photography, real estate, search and rescue, and "dirty and dangerous" jobs). The fourth Benefit Frame addresses the issue of global competitiveness with a stated concern that the U.S. will fall behind without implementation of domestic UAV flights.

Two Risk Frames were identified. One addresses privacy concerns from UAVs and the other safety. The final frame encompassed legal issues. The Regulation Frame described the importance of government action in establishing rules for UAVs that will benefit the public. Articles falling in this category discussed the Congressional mandate to allow domestic unmanned flight, the role of the FAA, the responsibility of government actors to establish appropriate regulations, and intergovernmental questions regarding jurisdiction over UAVs. Each story was read in its entirely and analyzed for content. The following information was coded by the authors for each article:

1) The Primary Frame, which is the frame found in the first or lead paragraph.

2) Any Secondary Frames that are present. These are frames appearing in the story other than the lead paragraph(s).

3) If one or more UAV applications are included in the article, the type of application (e.g., criminal justice or non-criminal justice).

4) The sponsor or policy actor of the first three statistics, quotes, or journalist paraphrased statements appearing in the article.

The sponsors were classified as falling within one of the following six subgroups:

I. Lawmaker (local, state, and national),

II. Agency (any level of government), 
III. UAV industry (trade association and individuals describing their UAV businesses),

IV. Public interest groups focused on privacy (American Civil Liberties Union, Electronic Frontier Association),

V. University officials, and

VI. Citizens (any person not associated with any of the other sponsor categories). Statements regarding UAV domestic implementation attributed to the category designated "citizens" were further classified as either a) For, b) Against, or c) Mixed.

The two authors did the coding. Using Holsti's formula (Holsti, 1969), the reliability score exceeded .80 for all categories coded.

\section{RESULTS AND DISCUSSION}

An analysis of frames in the media reports of domestic UAVs shows that the number of reports increased between 2011 through 2013, with a drop between 2013 and 2014. Between 2011 and the end of 2014, the content of media frames shifted as did sponsor attributions.

Table 1 displays the Primary Frames in the media reports, the most prominent elements in the text. Consistent with media framing studies of other emerging technologies, the positive or Benefit Frames dominated (Anderson et al., 2005; Lively et al., 2012; Nisbet \& Huge, 2006; B. Scheufele, 2006). Risk Frames rose sharply between 2011 and 2012, primarily as a result of concerns over privacy. Privacy risks peaked in 2012. Concerns over safety have been relatively low, reaching $6 \%$ in 2014, the highest of the four years examined. Of the Benefit Frames, economic development, in particular, has dominated coverage of domestic UAVs (Fig. 3). Although falling slightly between 2013 and 2014, the Economic Development Frame has been 
222 paramount every year analyzed. In 2013 and 2014, Economic Development and Citizen

223 Advocacy constituted 70\% of the Primary Frames. Many of these reports with an Economic

224 Development Frame used statistics provided by the Association for Unmanned Vehicle Systems

225 International (AUVSI), the UAV industry's largest trade organization. In 2013, the AUVSI had

226 issued an "Economic Report" that generated considerable press attention. The report predicted

227 that within three years, the domestic implementation of UAVs would create more than 70,000

228 jobs in the U.S. and have an economic impact of $\$ 13.6$ billion. By 2025, the economic impact

229 would increase to $\$ 82$ billion (AUVSI, 2013).

230 Table 1. U.S. media reports of domestic UAVs--Lead paragraph frames

\begin{tabular}{|c|c|c|c|c|}
\hline & 2011 & $2012^{1}$ & 2013 & 2014 \\
\hline \multicolumn{5}{|l|}{ Benefit Frames } \\
\hline$\overline{\text { Economic Development }}$ & $55 \%$ & $52 \%$ & $62 \%$ & $60 \%$ \\
\hline Citizen Advocacy & $5 \%$ & $4 \%$ & $8 \%$ & $10 \%$ \\
\hline Applications & $21 \%$ & $9 \%$ & $7 \%$ & $8 \%$ \\
\hline Global Competition & $4 \%$ & $3 \%$ & $1 \%$ & $2 \%$ \\
\hline Total & $85 \%$ & $68 \%$ & $78 \%$ & $80 \%$ \\
\hline \multicolumn{5}{|l|}{$\underline{\text { Risk Frames }}$} \\
\hline$\overline{\text { Privacy }}$ & $8 \%$ & $19 \%$ & $12 \%$ & $6 \%$ \\
\hline Safety & $2 \%$ & $4 \%$ & $4 \%$ & $6 \%$ \\
\hline Total & $10 \%$ & $23 \%$ & $16 \%$ & $12 \%$ \\
\hline \multicolumn{5}{|l|}{ Regulation Frame } \\
\hline$\overline{\text { Legal }}$ & $5 \%$ & $9 \%$ & $6 \%$ & $8 \%$ \\
\hline $\mathbf{N}=$ & 300 & 416 & 652 & 505 \\
\hline
\end{tabular}




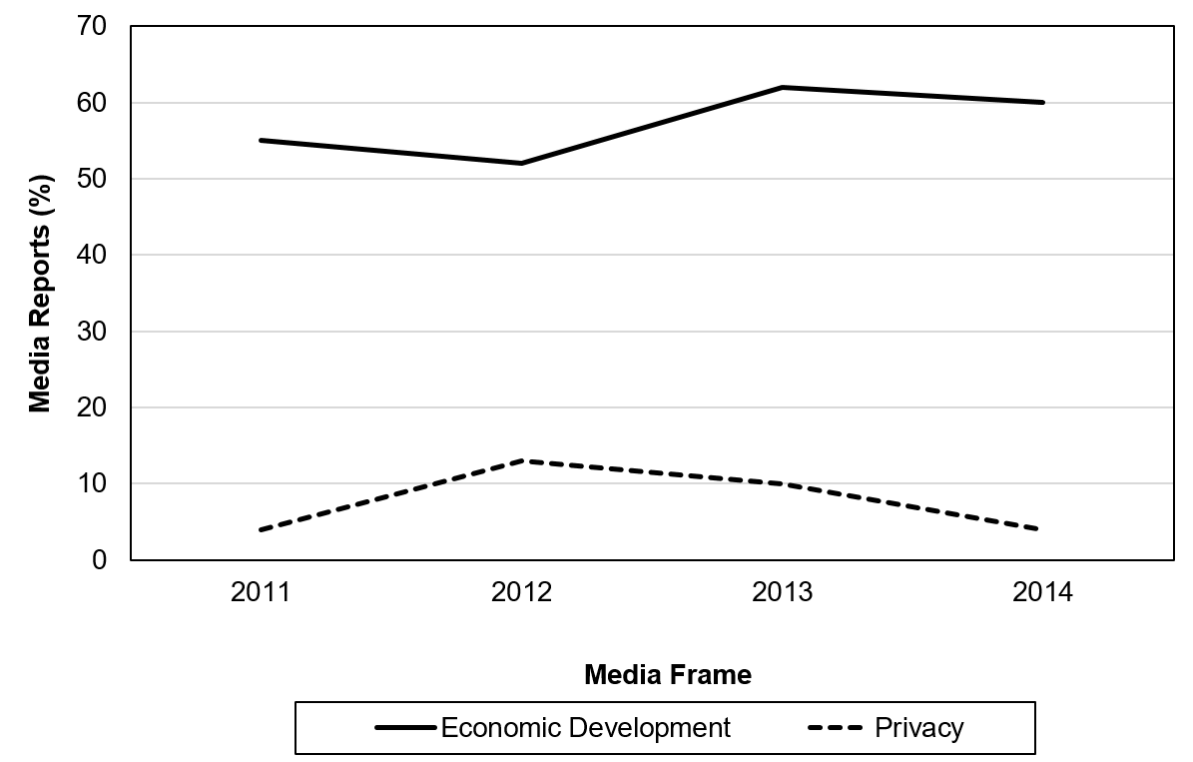

Fig. 3. Primary frames of annual U.S. media reports on domestic UAVs

A media report may have multiple frames. Table 2 displays all of the frames, both primary and secondary, displayed in the media stories analyzed from 2011 through 2014 . The percentages of stories each year containing each type of frame are displayed. These data reinforce the findings from Table 1; Benefit Frames are more frequent than Risk Frames. The Economic Development Frame has appeared in over two-thirds of the media reports all four years examined. These findings parallel the research of others, who conclude that science reporting is often positive, especially during early coverage of a new technology or scientific discovery. Reports often mention economic benefits (Friedman \& Egolf, 2005). 
Table 2. U.S. media reports of domestic UAVs_-Primary and secondary frames ${ }^{2}$

\begin{tabular}{|c|c|c|c|c|}
\hline & 2011 & $2012^{1}$ & 2013 & 2014 \\
\hline \multicolumn{5}{|l|}{ Benefit Frames } \\
\hline$\overline{\text { Economic Development }}$ & $72 \%$ & $69 \%$ & $76 \%$ & $82 \%$ \\
\hline Citizen Advocacy & $8 \%$ & $10 \%$ & $22 \%$ & $25 \%$ \\
\hline Applications & $35 \%$ & $32 \%$ & $51 \%$ & $44 \%$ \\
\hline Global Competition & -- & -- & $3 \%$ & $4 \%$ \\
\hline Total & $81 \%$ & $77 \%$ & $84 \%$ & $86 \%$ \\
\hline \multicolumn{5}{|l|}{$\underline{\text { Risk Frames }}$} \\
\hline Privacy & $13 \%$ & $30 \%$ & $45 \%$ & $32 \%$ \\
\hline Safety & $9 \%$ & $28 \%$ & $31 \%$ & $33 \%$ \\
\hline Total & $18 \%$ & $39 \%$ & $54 \%$ & $38 \%$ \\
\hline \multicolumn{5}{|l|}{ Regulation Frame } \\
\hline$\overline{\text { Legal }}$ & $7 \%$ & $31 \%$ & $40 \%$ & $44 \%$ \\
\hline $\mathbf{N}=$ & 300 & 416 & 652 & 505 \\
\hline
\end{tabular}

$245 \quad{ }^{2}$ Column totals can exceed $100 \%$ because an article can have multiple frames.

246 Citizen Advocacy increased substantially after 2012. U.S. competitiveness, while never

247 reaching 1\% of the Primary Frames in any year, appeared when considering Secondary Frames.

248 Successful frames emphasize the culture's values (Maddison \& Watts, 2011). Two themes

249 within the Benefit Frame (Citizen Advocacy and Global Competition) emphasize key values in

250 U.S. culture, which are individualism and competitiveness (Bellah, Madsen, Sullivan, Swidler,

251 \& Tipton, 1991). While the individual liberty value emphasized by UAV opponents focused on

252 the loss of privacy, media reports shifted from frames encompassing "personal freedom" to avoid

253 surveillance to "personal freedom" to use a UAV (i.e., Citizen Advocacy). Frames focusing on

254 the international competitiveness of the U.S. would likely garner media attention.

255 Risks Frames increased after 2011, probably because the Congressional mandate to integrate

256 flight domestically produced a political backlash in some U.S. states. Privacy concerns rose

257 considerably in 2012-2013; safety themes have risen every year. This shift is consistent with

258 patterns found in other studies when negative problems become apparent, coverage of the

259 science shifts toward negative (Nisbet, Brossard, \& Kroepsch, 2003; Nisbet \& Lewenstein, 
2002; Roth, Dunsby, \& Bero, 2003). The percentage of articles with a Regulation Frame jumped from $7 \%$ to $31 \%$ in 2012 and increased to a high of $44 \%$ of all 2014 articles.

Table 3 shows the types of domestic applications discussed in the media reports. For each media article that included a UAV application, the type of implementation was categorized into one of three categories: law enforcement, non-law enforcement, and a combination of both law enforcement and non-law enforcement. There has been significant apprehension regarding police use of UAVs (Straub, 2014). The number of articles examining law enforcement applications of UAVs increased from 2011 to 2012 but declined after 2012. Applications outside of law enforcement, which are generally non-controversial, fell from 2011 to 2012, but increased again. Thus, discussions of applications after 2012 shifted away from the relatively controversial use of UAVs in law enforcement.

\begin{tabular}{|c|c|c|c|c|}
\hline Application & 2011 & $2012^{1}$ & 2013 & 2014 \\
\hline None Given & $27 \%$ & $31 \%$ & $25 \%$ & $26 \%$ \\
\hline Law Enforcement & $24 \%$ & $29 \%$ & $19 \%$ & $15 \%$ \\
\hline Other & $34 \%$ & $24 \%$ & $38 \%$ & $46 \%$ \\
\hline Law Enforcement + Other & $15 \%$ & $16 \%$ & $18 \%$ & $13 \%$ \\
\hline $\mathbf{N}=$ & 300 & 416 & 652 & 505 \\
\hline
\end{tabular}

For controversial issues, policy actors may compete in "frame contest" in an attempt to dominate media framing (Carragee \& Roefs, 2004; W. Gamson, 2005; Watts \& Maddison, 2012). In this study, sources are analyzed to answer two questions. First is the extent to which a variety of sources are included in the media reports. Second is whether some sources are more predominant than others (Stephens, 2005).

Of particular interest is the proportion of non-elite sources. Research has shown that business interests and university-associated individuals dominate as sources in media covering emerging technologies (Hornig Priest \& Talbert, 1994; Nisbet \& Lewenstein, 2002). Because 
281 of the controversy surrounding UAVs and the likelihood that many in the public have an

282 understanding of their potential risks and benefits, the statements attributed to the general public,

283 or citizens, received a close examination.

284 For each media story the policy actor or sponsor of the first three statistics, quotes and

285 journalist paraphrased statements were coded (W. Gamson, 2005; Watts \& Maddison, 2012).

286 Table 4 displays the distribution of sponsors for media statements regarding domestic UAVs

287 across the articles examined. Several trends should be noted. Consistent with research on other

288 technologies, industry dominated as sponsors every year followed by university officials. Both

289 groups would benefit from domestic implementation; the UAV industry has been pushing

290 expansion (AUVSI, 2013) and researchers and universities seek favorable attention and perhaps

291 increased funding that UAV research may bring. Second, neither non-elected government

292 officials nor privacy interest groups exceeded $10 \%$ of the attributions in any of the years

293 examined. Lawmaker attributions peaked in 2013, then fell to $12 \%$. Despite attempts by groups

294 such as the American Civil Liberties Union and the Electronic Frontier to call attention to

295 potential problems created by the integration of unmanned flight, their positions received limited

296 media attention. The drop in lawmaker-sponsored statements may relate to the decline in concern

297 for privacy. Attributions to citizens commenting on UAV legalization increased from 2011 to

2982014. 
Table 4. Sponsors of statements in U.S. media reports regarding UAV domestic expansion ${ }^{2}$

\begin{tabular}{lcccc}
\hline Origin & $\mathbf{2 0 1 1}$ & $\mathbf{2 0 1 2}^{\mathbf{1}}$ & $\mathbf{2 0 1 3}$ & $\mathbf{2 0 1 4}$ \\
\hline UAV Industry & $59 \%$ & $42 \%$ & $44 \%$ & $53 \%$ \\
Lawmaker & $11 \%$ & $17 \%$ & $19 \%$ & $12 \%$ \\
Govt. Agency & $5 \%$ & $8 \%$ & $5 \%$ & $8 \%$ \\
University & $23 \%$ & $21 \%$ & $19 \%$ & $20 \%$ \\
Privacy Group & $5 \%$ & $5 \%$ & $6 \%$ & $4 \%$ \\
Citizen & $9 \%$ & $13 \%$ & $15 \%$ & $19 \%$
\end{tabular}

$\mathbf{N}=\quad 300 \quad 416 \quad 652 \quad 505$

\footnotetext{
${ }^{1} 2012$ U.S. Congress enacted the Modernization and Reform Act (PL112-95)

${ }^{2}$ Column totals can exceed $100 \%$ because up to three sponsors per article were coded.
}

302 Citizen attributions within the frames shifted during toward a more positive view of UAVs.

303 Fig. 4 shows the percentage of citizen attributions that were positive toward expansion. In 2011,

304 about one-half of statements by citizens commenting on domestic UAV use were positive.

305 Support by citizens dropped in 2012, but increased by 20\% in 2013 and reached $74 \%$ in 2014 .

306 Thus, there was a substantial increase in supportive statements by citizens in 2013 and 2014

307 compared to 2011 and 2012.

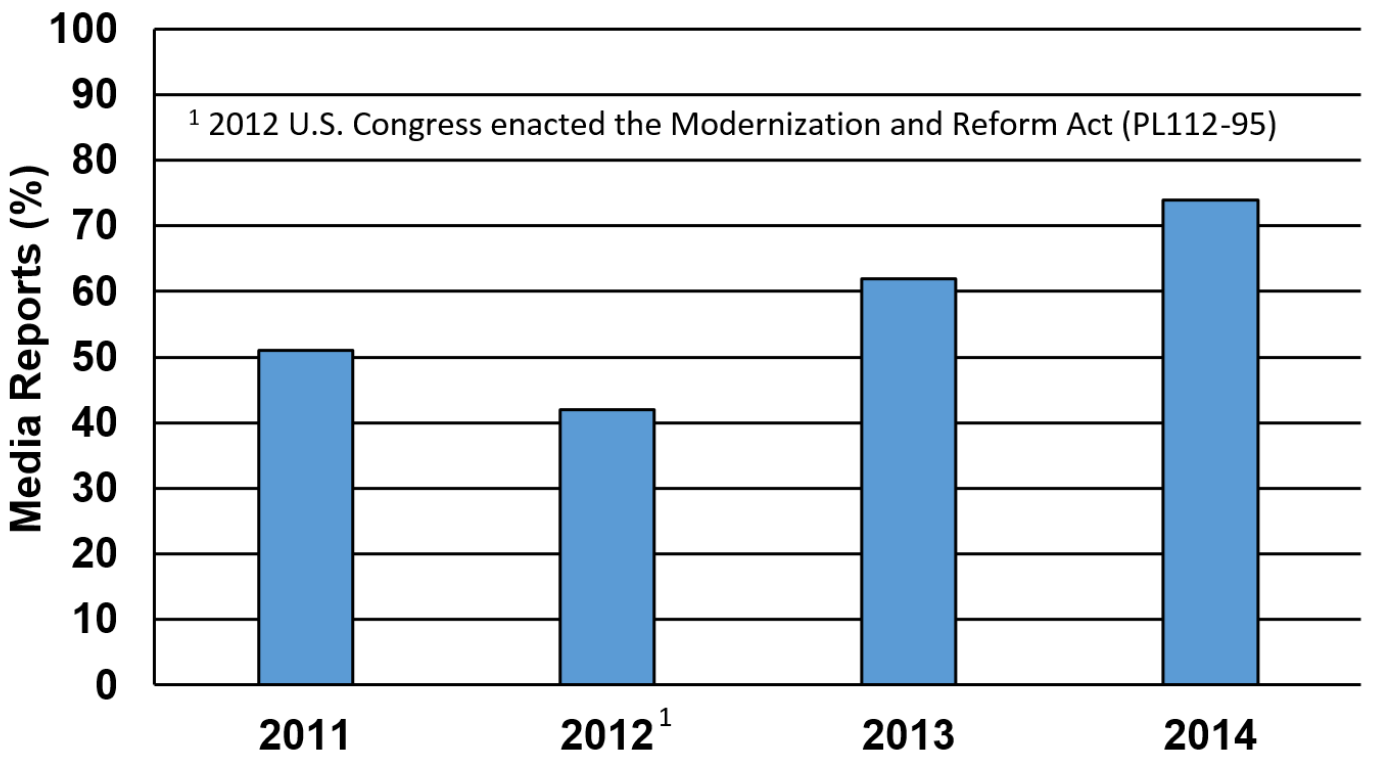

Fig. 4. U.S. media reports with positive UAV statements attributable to citizens

The impact of these media frames at this point can only be speculative. A frame may affect the way individuals perceive a problem, and therefore possibly alter their evaluation of the issue (Slothuus, 2008). There is no direct relationship between media framing and public opinion; an 
313 individual's interpretation of what is reported in the media is affected by numerous factors

314 including trust patterns, attitudes, beliefs, values, and associations (Hornig Priest, 2004; Nisbet

315 \& Huge, 2007). Nonetheless, research has linked public opinion of a technology to its coverage

316 in the media. For example, there are several studies that suggest a connection between public

317 attitudes towards nanotechnology and the media framing of nanotechnology (Fitzgerald \&

318 Rubin, 2005; Lee, Scheufele, \& Lewenstein, 2005; D. A. Scheufele \& Lewenstein, 2005).

319 Although Risk Frames jumped substantially with the mandate to implement unmanned flight

320 within the U.S., the proportion of Risk Frames had fallen in 2014. Change in the proportion of

321 various frames and in the types of UAV applications in the media reports suggest some reasons

322 for the decline. Although some of the news articles reported positively on the use of UAVs in

323 law enforcement, the legislative action to restrict police use demonstrate strong opposition

324 among citizens (National Conference of State Legislatures, 2015). The media shift away from

325 law enforcement toward less controversial applications perhaps contributed to the increasing 326 proportion of Benefit Frames. As news of UAV applications in agriculture, photography, and

327 other fields multiplied, media stories describing citizen support for expansion increased. Another

328 factor to be considered is the dominance of the UAV industry as a sponsor of the media

329 statements. Industry has provided virtually all of the estimates of economic impact.

330 The pattern of positive frame domination regarding media framing of domestic UAVs could 331 change. Unrealistic expectations of the contributions of a technology can produce a shift in 332 frames (Fox, 2013; Master \& Resnik, 2013; Ruef \& Markard, 2010), as can an accident or 333 other unanticipated event. The highly positive frame of progress was replaced by Negative 334 Frames in discussions of nuclear power after accidents at Three Mile Island and Chernobyl (W. 335 A. Gamson \& Modigliani, 1989). An airplane crash caused by unmanned flight, one or more 
accidents causing severe injury or death from a UAV, or a major scandal concerning privacy could shift attention to one of the negative frames. UAV advocates have struggled to counter images of robotic surveillance and armed drones operating within the U.S. Given that only $23 \%$ of the American public trusts the federal government to do mostly right (Horrigan \& Rainie, 2015), sentiment could shift quickly against unmanned flight and media attention would capture that perspective.

\section{SUMMARY AND CONCLUSIONS}

The mass media serves a crucial role in providing scientific and technological information to

the public. Media depictions can be a significant influence on the images formed around emerging technologies and may contribute to the interpretation given to an emerging technology's uses and impact.

This analysis of media frames regarding the integration of unmanned flight within the U.S. shows that despite considerable political activity designed to limit unmanned flight, Benefit Frames were far more prevalent than Risk Frames. The economic opportunities presented by UAVs appeared in most media reports and two groups who would benefit the most from domestic expansion, industry and university officials, dominated as sponsors of media statements. News stories regarding citizen advocacy to fly a UAV increased. Concerns over privacy declined by 2014 while citizen advocacy themes have increased. Although safety themes have increased, safety appears in a relatively small percentage of the media reports.

Most people in the U.S. can probably visualize a UAV and have some understanding of their risks as well as potential contributions. These characteristics set them apart from certain other technologies, such as nanotechnology. However, these findings regarding media coverage parallel the media framing reported for other emerging technologies. The dominant frame is 
359 positive, although media also report risks. There is an emphasis on potential economic benefits

360 produced by the technology. Controversy increased media coverage of possible technology

361 perils.

362 Possible shortcomings of this research should be noted. There may be sampling bias in the 363 selection of keywords that did not use the word "drone". Articles that use "drone", which some 364 view as a derogatory or militaristic term, and did not contain the word "unmanned", may have 365 contained more Risk Frames.

366 The controversy surrounding domestic unmanned flight is relatively new. As regulations are 367 developed to govern UAVs and knowledge increases regarding their capabilities, media frames 368 will likely change. Future research might consider whether there is variance in frames across 369 different types of media. Newspapers may differ from social media. The national media supply 370 coverage beyond the local news.

371 While media coverage of certain technologies can be so dominated by Positive Frames that 372 discussions become depoliticized (Lively et al., 2012), politics are likely to remain essential for 373 unmanned flight. The FAA has not yet finalized regulations, and the states have adopted a wide 374 variety of laws. Federalism issues are far from resolved. Thus, the framing of this emerging 375 technology will likely continue to evolve.

\section{ACKNOWLEDGEMENT}

377 This work was supported by the USDA National Institute of Food and Agriculture, Hatch Project

378 TN00459. Any opinions, findings, conclusions, or recommendations expressed in this publication are

379 those of the authors and do not necessarily reflect the view of the National Institute of Food and

380 Agriculture (NIFA) or the United States Department of Agriculture (USDA). 


\section{BIBLIOGRAPHY}

Abrahamson, M. (1983). Social research methods: Prentice Hall.

Anderson, A., Allan, S., Petersen, A., \& Wilkinson, C. (2005). The framing of nanotechnologies in the British newspaper press. Science communication, 27(2), 200-220.

AUVSI. (2013). The Economic Impact of Unmanned Aircraft Systems Integration in the United States. Retrieved February, 2015, from https://qzprod.files.wordpress.com/2013/03/econ report full2.pdf

Bellah, R., Madsen, R., Sullivan, W. M., Swidler, A., \& Tipton, S. (1991). The good society. Alfred A: Knopf, New York.

Benford, R. D., \& Snow, D. A. (2000). Framing processes and social movements: An overview and assessment. Annual review of sociology, 611-639.

Bennett, W. C. (2012). Unmanned at any speed: bringing drones into our national airspace: Brookings.

Bohm, A. (2014). Status of 2014 Domestic Drone Legislation in the States. Retrieved January 24, 2015, from https://www.aclu.org/blog/technology-and-liberty/status-2014-domestic-drone-legislation-states

Boykoff, M. T. (2008). The cultural politics of climate change discourse in UK tabloids. Political geography, 27(5), 549-569.

Brewin, B. (2013). No Existing Technology Can Ensure Drone Safety, GAO Official Says. Retrieved February 22, 2015, from http://www.nextgov.com/defense/2013/02/no-existing-technology-can-ensure-drone-safety-gaoofficial-says/61384/

Carragee, K. M., \& Roefs, W. (2004). The neglect of power in recent framing research. Journal of Communication, 54(2), 214-233.

Chong, D., \& Druckman, J. N. (2007). A theory of framing and opinion formation in competitive elite environments. Journal of Communication, 57(1), 99-118.

de Vreese, C. H. (2012). New avenues for framing research. American Behavioral Scientist, 56(3), 365-375.

Di Gregorio, M., Price, S., Saunders, C., \& Brockhaus, M. (2013). Code book for the analysis of media frames in articles on REDD: CIFOR.

Dolan, A. M., \& Thompson, R. M. (2013). Integration of Drones into Domestic Airspace: Selected Legal Issues.

Elias, B. (2012). Pilotless drones: Background and considerations for Congress regarding unmanned aircraft operations in the national airspace system.

Entman, R. M. (1993). Framing: Toward Clarification of a Fractured Paradigm. Journal of Communication, 43(4), 51-58.

Entman, R. M., Matthes, J., \& Pellicano, L. (2009). Nature, sources, and effects of news framing. The handbook of journalism studies, 175-190.

Ferguson, B. (2007). Photo: MQ-9 Reaper in flight (2007).jpg - Wikipedia, the free encyclopedia. Retrieved 7-July2015, from https://en.wikipedia.org/wiki/File:MQ-9 Reaper_in flight_(2007).jpg

Fitzgerald, S., \& Rubin, B. (2005). Constructing risk: Media coverage of nanotechnology. Paper presented at the annual meeting of the American Sociological Association, Montreal Convention Center, Montreal, Quebec, Canada.

Fox, S. (2013). The innovation big picture: Including effectiveness dependencies, efficiency dependencies, and potential negative effects within the framing of new technologies. Technology in Society, 35(4), 306-314.

Friedman, S. M., \& Egolf, B. P. (2005). Nanotechnology: risks and the media. IEEE Technol. Soc. Mag., 24(4), 5-11.

Gamson, W. (2005). Movement impact on cultural change. Culture, power and history: Studies in critical sociology. The Netherlands: Brill Academic Publishers.

Gamson, W. A., \& Modigliani, A. (1989). Media discourse and public opinion on nuclear power: A constructionist approach. American journal of sociology, 1-37.

GAO. (2012). Unmanned Aircraft Systems: Measuring Progress and Addressing Potential Privacy Concerns Would Facilitate Integration into the National Airspace System [Reissued on September 18, 2012]. from http://www.gao.gov/products/GAO-12-981

Gitlin, T. (1980). The whole world is watching: Mass media in the making \& unmaking of the new left: Univ of California Press.

Goodman, J. D. (2013). Remote-Controlled Model Helicopter Fatally Strikes Its Operator. NY TIMES (Sept. 5, 2013), http://www. nytimes. com/2013/09/06/nyregion/remote-controlled-copter-fatally-strikespilot-at-park. html.

Hart, R. P. (Ed.). (2014). Communication and Language Analysis in the Public Sphere. Hershey, PA, USA: IGI Global.

Holsti, O. R. (1969). Content analysis for the social sciences and humanities. 
Hornig Priest, S. (2004). Biotechnology, media and public opinion across national boundaries. Ecquid Novi, 25(1), 80-93.

Hornig Priest, S., \& Talbert, J. (1994). Mass media and the ultimate technological fix: Newspaper coverage of biotechnology. Southwestern Mass Communication Journal, 10(1).

Horrigan, J. B., \& Rainie, L. (2015). Americans' Views on Open Government Data. Retrieved 6-July-2015, from http://www.pewinternet.org/2015/04/21/open-government-data/

Jones, C. (2014). Back from the battlefield: Domestic drones in the UK. London: Statewatch/Drone Wars UK.

Kaminski, M. E. (2013). Drone Federalism: Civilian Drones and the Things They Carry. Calif. L. Rev. Circuit, 4, 57209.

L'Etang, J., \& Merkelsen, H. (2011). The double-edged sword of legitimacy in public relations. Journal of Communication Management, 15(2), 125-143.

Lee, C.-J., Scheufele, D. A., \& Lewenstein, B. V. (2005). Public attitudes toward emerging technologies examining the interactive effects of cognitions and affect on public attitudes toward nanotechnology. Science communication, 27(2), 240-267.

Lively, E., Conroy, M., Weaver, D., \& Bimber, B. (2012). 11 News Media Frame Novel Technologies in a Familiar Way: Nanotechnology, Applications, and Progress. In B. Herr Harthorn \& J. Mohr (Eds.), The social life of nanotechnology (pp. 223-240). New York, NY: Routledge.

MacGillis, A. (2013). Don't Fear the Reaper Two days with the extremely anxious drone lobby. Retrieved February 22, 2015, from http://www.newrepublic.com/article/112494/drone-lobby-works-its-image-problem

Maddison, J., \& Watts, R. (2011). The technological fix as a frame in media debates about tailpipe emissions. Technology in Society, 33(3), 294-303.

Master, Z., \& Resnik, D. B. (2013). Hype and public trust in science. Science and engineering ethics, 19(2), 321335 .

McGarry, B. (2012). Drones most accident-prone US Air Force craft: BGOV Barometer. Bloomberg. com.

Morley, J. (2012). Drones' new weapon: P.R. Retrieved February 22, 2015, from http://www.salon.com/2012/05/22/drones_new_weapon_p_r/

Nanjia, S. (2014). Commercial Drone Privacy Laws May Face Legal Challenges - Law360. Retrieved April 28, 2014, from http://www.law360.com/articles/500480/commercial-drone-privacy-laws-may-face-legalchallenges

National Conference of State Legislatures. (2015). Current Unmanned Aircraft state Law Landscape. May 22., from http://www.ncsl.org/research/transportation/current-unmanned-aircraft-state-law-landscape.aspx

NewsBank Inc. (2015). Access World News: Research Collection. Retrieved Nov-11-2015, from http://www.newsbank.com/libraries/colleges-universities/solutions/us-international/access-world-newsresearch-collection

Nisbet, M. C., Brossard, D., \& Kroepsch, A. (2003). Framing science the stem cell controversy in an age of press/politics. The International Journal of Press/Politics, 8(2), 36-70.

Nisbet, M. C., \& Huge, M. (2006). Attention cycles and frames in the plant biotechnology debate managing power and participation through the press/policy connection. The Harvard International Journal of Press/Politics, $11(2), 3-40$.

Nisbet, M. C., \& Huge, M. (2007). Where do science debates come from? Understanding attention cycles and framing. D. Brossard, J. Shanahan, and TC Nesbitt. The media, the public and agricultural biotechnology. CAB International, Wallingford, UK, 193-230.

Nisbet, M. C., \& Lewenstein, B. V. (2002). Biotechnology and the American media the policy process and the Elite Press, 1970 to 1999. Science communication, 23(4), 359-391.

Pan, Z., \& Kosicki, G. M. (2001). Framing as a strategic action in public deliberation. Framing public life: Perspectives on media and our understanding of the social world, 35-65.

Polletta, F., \& Ho, M. K. (2006). Frames and their consequences. The oxford handbook of contextual political analysis, 189-209.

Rainwater, S. (2013). Texas Declares War on Robots. Retrieved February 22, 2015, from http://robots.net/article/3542.html

Reese, S. D., Gandy Jr, O. H., \& Grant, A. E. (2001). Framing public life: Perspectives on media and our understanding of the social world: Routledge.

Roth, A. L., Dunsby, J., \& Bero, L. A. (2003). Framing processes in public commentary on US federal tobacco control regulation. Social Studies of Science, 33(1), 7-44.

Ruef, A., \& Markard, J. (2010). What happens after a hype? How changing expectations affected innovation activities in the case of stationary fuel cells. Technology Analysis \& Strategic Management, 22(3), 317-338. 
doi: 10.1080/09537321003647354

Scheufele, B. (2006). Frames, schemata, and news reporting. Communications, 31(1), 65-83.

Scheufele, D. A., \& Lewenstein, B. V. (2005). The public and nanotechnology: How citizens make sense of emerging technologies. Journal of Nanoparticle Research, 7(6), 659-667.

Slothuus, R. (2008). More Than Weighting Cognitive Importance: A Dual-Process Model of Issue Framing Effects. Political Psychology, 29(1), 1-28.

Slothuus, R., \& de Vreese, C. H. (2010). Political parties, motivated reasoning, and issue framing effects. The Journal of Politics, 72(03), 630-645.

Smith, A. (2014). U.S. Views of Technology and the Future: Pew Research Center.

Smith, M. A. (2000). American business and political power: public opinion, elections, and democracy: University of Chicago Press.

Steinmetz, K. (2014). Colorado Town Won't Issue Drone-Hunting Licenses. Retrieved February 22, 2015, from http://time.com/46327/drone-hunting-deer-trail/

Stephens, L. F. (2005). News narratives about nano S\&T in major US and non-US newspapers. Science communication, 27(2), 175-199.

Straub, J. (2014). Unmanned aerial systems: Consideration of the use of force for law enforcement applications. Technology in Society, 39, 100-109.

Sullivan, A. B. (2013). Iowa City Could be Among First in Nation to Ban Drones. Retrieved July 11, 2013, from http://www.desmoinesregister.com/article/20130606/NEWS/130606002/Iowa-City-could-be-among-firstin-nation-to-ban-drones?Frontpage

Traverse, N. (2013). Idea of the Week: The Drone Economy. The New Yorker.Retrieved 18-Nov-2015, from http://www.newyorker.com/news/news-desk/idea-of-the-week-the-drone-economy

Villasenor, J. (2013). Privacy, security, and human dignity in the digital age: Observations from above: Unmanned aircraft systems and privacy. Harv. JL \& Pub. Pol'y, 36, 457-1245.

Watts, R., \& Maddison, J. (2012). The role of media actors in reframing the media discourse in the decision to reject relicensing the Vermont Yankee nuclear power plant. Journal of Environmental Studies and Sciences, 2(2), 131-142.

Whitlock, C. (2014). When drones fall from the sky. Retrieved February 22, 2015, from http://www.washingtonpost.com/sf/investigative/2014/06/20/when-drones-fall-from-the-sky/ 